\title{
The Measure of the Poetics in Raduan Nassar's Um Copo de Cólera
}

\author{
Elijames Moraes dos Santos, Eloima Carvalho Pires \\ States University of Piauí, Teresina, Brazil
}

\begin{abstract}
This article took form after the reading of the novel Um Copo de Cólera by Raduan Nassar, under a systemic perspective of the semiotics of culture. The objective of this work is to show how the subsystems act over the structure of the poetic language of this literary creation, as well as the points of confrontation that move the narrative through the flow of the translation of the text from the primary to secondary modeling, promoting a dialogue unit to the text whose process enables the reader to interact and enlarge his or her horizon of expectations. The novel is organized in seven chapters formed by unique paragraphs with an accurate language from stylistic features and characteristics of Nassar's writing, when elaborating the contrasts which delineate the identity marks of the characters involved in the literary plot. To achieve the purposes already set, we will use the theoretical studies of Iúri Lótman (1979) and his follower Irene Machado (2003) with regard to the typology compendiums of the culture and the poetic language. For the aspects related to the enjoyment of literary writing, we will use the studies of Roland Barthes in O Prazer do Texto (2002).
\end{abstract}

Keywords: Um Copo de Cólera, semiotics of culture, poetics

\section{Introduction}

Divided into seven chapters and a unique paragraph, the novel Um Copo de Cólera by Raduan Nassar, designs a lirism poetic within what is referred to narrative discursive aspects in its hierarchy organization. Then, we have a reduced space to set the plot, where the actions of two characters are performed mimetically, whose identities are characterized by the pronominalization, which does not disallow, but reinforces the voices of the diegetic universe that surrounds the narrative involved by the characters' flow. In this way, the time cannot be defined, at first, as chronologic but as inter-place where memories presented in the inter-discuss of actions summarize the expressive resources and in this way, make true the specific dynamism of the gender in question.

From these elements which constitute the work in analysis literarity, it is highlighted that a poetic language inserted of contrasts once translates the lirism, once questions the empiric reality which approaches the narrative of daily happenings that complement the reader experience. So, Nassar's writing presents very particular characteristics which involve and fascinate even the most unsuspecting look, due to the organic metaphors that are inserted in all chapters of the corpus in analysis, according to the sequence: The Arrival, In Bed, The Get up, The Bath, The Morning Breakfast, The Fighting, and The Arrival.

Elijames Moraes dos Santos, master, Language and Literature Department, States University of Piauí. Eloima Carvalho Pires, master, Language and Literature Department, States University of Piauí. 
This circularity, already presented in the chapters titling, limits the organizational structure in terms of nominal confluence both to the first and to the seven chapters, which despite being homonymous are divergent towards the narrator profile, due to the fact that from the beginning until the sixth chapter, the narrative is performed by the protagonist narrator, which is the small farmer- "he" (Nassar, 1987, p. 81) - and in the first person, yet in the seven chapter there is an inversion, when the journalist takes the narrative- "she" (Nassar, 1987, p. 7) - therefore, keeps the narrative focus in the first person.

Nevertheless, the novel under study despite being organized in seven chapters, which means 85 pages can be objectively divided in two parts. The first, that includes the first five chapters, describes the happenings automatized by the routine, getting closer to the empirical reality, highlighted by the usual living together that comes to establish a consensual distance, in terms of the discursive subjects, emphasizing the silence in this narrative inserting. Made out of a brief text, the first part authorizes the reader to participate in the events that coordinate the actions of the character.

The second part includes the last two chapters, sixth and seventh respectively, being that the sixth entitled "The Fighting" overcomes the other chapters due to, not only more quantity in pages, but also for focusing the tension and unveiling the voices individualization, which make the articulated narrative center from incidents metaphorically represented by the accidental damage of the live fence done by the ants. Yet in the seventh and last chapter, there is a return to the initial situation, preserving the narrative focus in the first person, but changing the narrator's subject whose voice, now, is taken by the journalist. So, this last chapter "The Arrival", homonymous of the first, ends the novel, returning the circumscribed routine to the actions developed by the main characters previously announced in the starting chapter.

Having in mind the development of the happenings, it is intended in this work to revisit the theories related to the selected theme for analysis, according to the indication in the title "The Measure of the Poetics in Raduan Nassar's Um Copo de Cólera". In order to achieve this goal, some objectives were prepared, as: show how to articulate the subsystems that structure the poetic language of the novel Um Copo de Cólera; talk about the points of confrontation which mobilize the narrative in the translation way of the text from the primary and secondary modeling both linked to the theoretical studies of Lotman (1979) and his follower Irene Machado (2003) with regards to the typology systemic approach of culture and the poetic language. To these it is interfaced that a dialogic unit enables the reader to interact with the text and still enlarge his/her horizon of expectation in the aesthetics fruition that was pointed out in the studies of Roland Barthes (2002).

\section{Poetics Under a Semiotic Perspective Competence of Culture}

It is around language that it is concentrated theoretical perspectives of different studies, given the plurality and possibility of articulations. To understand procedures, stylistic resources, modeling, meanings, among others are concerns of scholars as the semioticists, in special the founders of Moscow Tartu School (MTS), who deal with the language as a built system from modeling of a natural language. To these Russian semioticists, modeling is a basic principle of systematic approach, to what Machado (2003) adds, "its goal is to achieve a knowledge about the world through its codes" (p. 146).

It is from this systematic approach, installed with semiotics of culture, that it will be observed the language structure, its organized codes as interactive processes, which end up in a semiotics competence. It is by this means of interaction that the competence is developed, "the domain of meaning production understood as source of production of semiosis itself or the language. [...] A dialogic capacity of creation of a language" 
(Machado, 2003, p. 147).

As language is an environment in plain development, place of interaction, changing, the theorists of this semiotics field use this complexity to expose their view about the signics systems that are covered with culture, representative element of natural world, where cultural codes belong to a natural system and can be recoded "when there is a moving of primary modeling systems (natural language) to the secondary" (Lotman, 1979, p. 33). In this way, the semiotics competence is understood as a modeling activity, that is, Irene Machado reinforces that "it was this semiotics competence creator of language that allowed the development [...] from non-culture to culture, making that culture could be understood as text" (Machado, 2003, p. 148). So, from the semiotics' perspective of MTS, culture is enjoyed as a text, in the "sense of kind of culture" (Lotman, 1979, p. $33)$.

The literary text, for instance, is a system surrounded by signs and images that allow the reader reflect about its structure built from elements, mostly referred in the world in which it is inserted. Nevertheless, in this study of culture as a text, it is proceeded that a semiosis builds an aesthetics form, while modelizing secondary in which the semiotics competence of language promotes in a dialogic way the construction of the text poetics, allowing even that the reader may add meanings before not mentioned by the work author himself. Meanwhile, Eco's words are true when dealing with a masterpiece as a closed system in its perfection, but capable of different interpretations, constituting it an open work, thus not altering its singularity. Then, the interpretation of the work converges to the fruition field, an action that enables the renewing of the sense of the narrative despite object of analysis (Eco, 2013).

In this poetics performance, according to the principles of semiotics of culture, the reader is part of this job, having him/her the role of expansion agent of the artistic language. Then, in the relations flow of culture competence, we look to literary test, overall to the novel Um Copo de Cólera hierarchy, corpus of this article, in order to refine the codes, as well as their signics traces, in the process of Nassarian poetic structure, whose narrative is moved by the silence of traces of a repression period of time, articulating expressive meanings in the construct of the work, making, in this sense, the reader's interaction with the text. In this way, fruition happens in a free and conscious manner, producing an endless relations net (Eco, 2013), in this signic system of culture called literary text.

To a better understanding of the text, despite semiotics system whose culture competence enables a dialogue in its hierarchical organization, it is necessary to point out, also, that this dynamic presents two plans, which Lotman (1979) says to be present "in concrete descriptions of texts [...], in the first plan [...] the basic peculiarity [...] of approach" (p. 132). So, in the second plan, there is a dynamic model built from "a certain quantity of static models".

In this way, these models are interrelated making subsystems inside the text structure, what Lotman (1979) calls the attention, "the acknowledgment of artistic life of the text understands these two approaches at the same time. Each one of them by themselves cannot represent the functions of the text, that is, its life" (p. 133). This interaction meets with the text meaning aspects, on one side, enriched by the reader towards the aesthetics fruition and its horizon of expectation.

In this measure of aesthetics creation, the enrichment of culture codes is promoted and it is highlighted in the description of the text structure, the static models which comprehend what can be called of form tradition, thus contributing to stylistic and meaningful dynamic, and still to the reader's acting his/her inferences during the artistic making. In this context, the life of the text is linked to a dialectics process, and in these terms, 
involves both the descriptive traditions, concerning the subsystems interpretation and the energetic level. That can be determined during the structure description of the work like the "essence of its aesthetics function" (Lotman, 1979, p. 137). Then, it is in this study view of culture that we enter the poetics of the novel Um Copo de Cólera by Raduan Nassar, through a vision that integrates the levels of a semiotics competence to the reader perception as a member of the process of meaning which converges to aesthetic pleasure.

\section{The Aesthetics of Interpretation}

The comprehension of the literary work, in its condition of artistic object, is not effective if dissociated from aesthetics experience in the interpretative act. Nevertheless, there must be considered interpretative limits in the analysis process, having in mind the possibilities that the work authorizes as permissive in the field of intentionality, without, therefore, entering the convenience relations.

Starting from the critic to the phenomenon of interpretative permissivity, through which are delineated objectives distinct to the act of comprehension of the literary work, Eco (1993) reminds of the discussions towards the "text intention" (p. 29), having in mind the aspects of the incompleteness of the work, that is, its genesis structurally opens to different ways of reading and to the different process or remeaning of the text which relates, not only, to the interests of the reader, but also to the mediation of aesthetics experience that can only come to be deeply defined by immanent intentionality to the text.

With this, the intentionality of the text is not considered as an action circunscrite to the process of creation and/or interpretation, but as emancipation of the interpretative act, whose meaning is presented mutable, given the linguistic functions that stimulate the aesthetics experience and broaden the meaning field denoted by the writing while means to the establishment of dialectics relations arouse in the literary text, before a multiplicity of connotative senses in the interpretation act.

Most importantly, the interpretative act demands knowledge of the work structure, the provokers effects of linguistic code in its formal organization when institutionalized codes as well as the relation ways of this code with the material elements constitute itself, changing it into a system of suggested reference and coordinated by the work and translated into different levels which enable the acknowledgement of the work while object with aesthetics quality, "that do not account for internal formal relations in the work, but to the relations of the work with its fruitors and to the relations of the work with the historical/cultural context that it comes from" (Eco, 2011, P. 91).

Thus, the interpretative practice does not correspond to the manifestations of linguistics aspects identified by the material elements as "object, the system of reference to which the work is related, the system of psychological relations that the work creates and coordinates, etc." (Eco, 2011, p. 89), which allows the insertion of the work under work in several literary contexts, but the conversion of the institutionalized code in an individualized sign by the conscious and it is transformed into interpreter according to the referent object.

In these terms, the aesthetics pleasure is beyond emotions brought by the proximity with language, converging to enrichment of extra literary experience, which merges to the work elements away from everyday life. It is, then, the interpretative aesthetics, whose essence starts in the narrative structure and comes from the noncompliance to aspects that integrate the poetics of the literary text and to conventionalize it as sign, according to criterion given to the interpretative act. "If there is anything to be interpreted, the interpretation must be spoken of something that must be found somewhere, and in certain ways respected" (Eco, 1993, p. 51).

For sure, the exercise of interpretation should not run away from the text, and overall must be careful 
towards the establishment of interpretative objectives, what runs to the importance of listening to the text, interacts with the intentionality prepared in its structure, having in mind that the references coming from the meaning process, despite of being endless, not always include the objectives intended by the text. In this sense, the interpretative itinerary must ensure the return to the text, stimulating the desautomatization of the look, when the appreciation of linguistics mechanisms is said as essential to the multiplication of meaning possibilities:

This makes that the meaning be multiform and not univocal and that the first phase of the comprehension process let us, at the same time, satisfied and dissatisfied by its own variety. That is why we return to the message, already enriched this time by a schema of complex meaning undoubtedly chases our memory of past experiences. (Eco, 2013, p. 85)

The interpretative operation, in these terms, is stated like a possibility of aesthetics experience that is mediated by the resource of similarity stimulating the imaginary like the perception of ambiguity of semantics. "In this sense, ambiguity is not an accessory characteristic of the message: It is the main point which takes the codifier to assume a different attitude towards the message" (Eco, 2011, p. 97). In other words, make the interpretative exercise an auto-reflexive procedure, not definitive, according to which are established the sense relations among text elements provokers of communicative tension.

In short, the interpretation act must be stimulated due to the increasing of immanent characteristics to the literary texts, but, above all the characteristics that challenge the reader to map the unknown, projecting $\mathrm{him} /$ herself to the possible imaginary field, conventionalized by desires, anxieties, and frustrations, coming from indefinite contexts, but determiners to the aesthetics pleasure obtainment, through which, becomes possible, broaden, limit, or ignore the interpretation possibilities of the literary work, identifying it despite mechanism of meaningful referentialization.

\section{The Poetics Effects Under the Culture View in Um Copo de Cólera}

When we turn our look to a literary text, it is possible to identify a number of effects forms disposed in the structures and coordinated by elements that constitute the work reference system, what creates in the reader the pre-willing to enter a route apparently already trailed, considering his/her knowledge and capacity to decode language, having in sight the work aspects, as a recognizable system in a cultural historical context. We walk towards semiotics of the culture using the systemic plans to analyze the poetics effects of Nassarian language in Um Copo de Cólera.

Like this, the reader faces the characters that make the plot of actions and proportionate a view of announced happenings, in part, by the conscience flow which is referenced, in the first chapters, by the deep silence of the small farmer. Such as noted in this excerpt:

[...] knowing that her eyes did stare at my mouth, and knowing that under her quietness she tumbled of impatiently, and knowing above all that the more I turned her on the more I seemed indifferent, [...] and not returning to the kitchen we met again in the corridor, and with no words we entered almost together in the darkness of the room. (Nassar, 1987, pp .8-9)

It is possible to note that, in this first part there is an immediate reference to factual behaviors, covered by the indifference among characters that almost do not talk, presuming a lack of commitment due to uncertainties made by values that particularize each one of the characters. Due to in certain moments the small farmer's voice allows the reader concludes the silences which last in the tentative of dialogue tried by the journalist: "[...] 
when she asked me 'what's the matter with you?', but I, feeling the strong smell of coffee coming in thick waves from the strainer in the kitchen, I said nothing, not even turned my face towards her [...]" (Nassar, 1987, p. 25). At this end, the open spaces provided by the silence can be filled during the process of remeaning of the work, constituting it in the differential of the referentialization process that according to Eco (2013) does not reside in the work, but in the receptor, having in sight that the denotative characteristic is situated in the suggestively field spoken by the author.

The silence projected along the narrative creates a tension as stylistics resource coming from articulation of conflicting elements in different levels of the novel under study. In this dynamic, it will be the reader's role in the perception of facts which is caught by the silence and that requires critic autonomy in the process of code translation, as a meaning element, which is renewed as each passage of Nassar's prose. In this way the recurrent silenciosity is shown, still, in passages like this: "[...] and where she was I felt she looked at me and smoked like me, but put in this some anxiety, certainly asking me [...] but I didn't care for this, I wanted the silence. [...]" (Nassar, 1987, p. 78).

In this modeling of aesthetics text we see a peculiar lirism of Nassarian writing, in which the culture subsystems are properly organized. Thus, the present elements in the static plan constitute the plot of the corpus, like characters, environment, moment, or time of narrative, converge to the second plan, the dynamic, in which the narrative action enables the receptor of the text involvement through the perception, assuring like this, the fruition of the literary make. Under the culture semiotic look, we may say "that the text has certain energetic indexes. [...] the description puts in its front the task not only to grasp the isolated levels of construction, but also to determine the essence of its aesthetic function as a whole" (Lotman, 1979, p. 137).

The silence intersections compound the narrative discussion in different parts of novel, showing revealing tensions of conflictual themes, in a fruition space in which the reader can, therefore, act as a subject of the interpretation process, enjoy the pleasure to collaborate with the creator task. Because, according to Barthes (2002) " $[\ldots]$ the fruition interstice, is produced in the languages volume, in the enunciation, not in the sequence of enunciates; [...]" (pp. 19-20). Then, we shall not wait that the text presents answers to the questions immanent to the narrative, but problematize the interpretation process, while activity of sense producer and that enlarge the dialectic relation between text and reader.

In this context, the lyric prose of the novel in analysis, proposes different levels of access to imaginary, using metaphors and comparisons like in the statements related to "he": "the timid way of tender root" and "two white lilies" (Nassar, 1987, pp. 11, 15), establishing the contrast between power and fragility. Yet in the comparison towards "she", the term "little vine" is pointed out (Nassar, 1987, p. 17); despite belonging to semantic field which relates to the flora, as well as root and lilies, it is possible to establish an euphemism in this signic system, resulting in a disjunctive process of the language, where the lirism overcomes poetics as sense resources are in the process of textual renewal.

The battle established between fragility and power is displayed in a dynamic subsystem, in which the tension arises in the narrative structure, through a reference to the dictatorship, hidden theme by the silences spaces projected all over the narrative, arises to the text surface, according to what we see in the except below:

[...] (she knew how to play her role) [...] telling me with such security "I don't understand how you change yourself, all of a sudden you become a fascist" she said this in a more or less serious way [...] feeding with dry wood the incipient fire that I pulled (I who was — methodically — mixing reasoning and emotion in a insolite chemist mixture), [...], anyway I had been hit, or other, actor, I only pretended, as an example, the pain that really hurt me [...]. (Nassar, 1987, pp. 36-37) 
It is revealed, in the narrative trajectory, that conflict points are structured in a dialogic segment of culture, which makes the literary creation an enriched environment by data belonging to the cultural memory, allowing the receptor to interact and rescue elements preserved in its heap of historical-cultural experience. Then, the silence that intercuts the narrative plot can be comprehended analogically as a repression look and behavioral regulator. The following exception gives some feasible aspects about the approaches theme:

The truth is that I got sick and tired of all these disputes among regret children from small burgess class, ingenuously competing in generosity with the softness of their boots, extracting from this comparative some fungus of liberty virtue, of this purification she liked, as much as purify at criticizing the middle class, this class almost always renegaded, hesitating maybe because of this between launching herself to the hawk's heights or insoling the ground with the simplicity of the sandals [...]. (Nassar, 1987, pp. 38-39)

Demonstrated the tensions, as underlined by Lotman (1979) the "essential quality of the artistic work" (p. 135), it is presented in a figurative relations, the observing of some conflicts generated between the couple main characters of the plot, as the forged conscience and a pretended commitment with social causes, considering that the individual satisfaction was preserved as a larger good, due to the fact that the dilemma lived by them was placed in the individual fulfillment space. "He" wanting to preserve himself behind a falsely strong fence, but does not resist the attacks of the ants and "she" wanting to project herself, exceeding the limits of that live-fence, to reach liberty. Matching, then, with this description we point out the fragment of the novel:

[...] I was inside myself (and what a mess!), I was hanging around with the confusion, with colic, with terrible contortions from a virus congestion, with fermented things in the pan of my stomach, all the things outside and my ants little by little carried, and they were great carriers the mother-fuckers, [...] someone has to be blamed of wishing or not, this was one of life's maximum, this was the hate spontaneous support. (Nassar, 1987, p. 41)

It is in this hatred impulse of the narrative that a common lirism is found, which intercalates the everyday themes proper of an undesired loving involvement but representative in a context of uncertainties feeded by the repression sign. This pretended undesiring intensifies the consistency of ephemerid that supports the frustrating experiences in search for liberty, what contradictorily is represented in the work by the sign of subjection; "he" stuck to the small farm space; "she" stuck to the body space; "both did not make a lot, just enough" (Nassar, 1987. P. 33). In this main actions articulation of the narrative discuss, the small farmer denies some values that support a masked order and choose to live according to his own rules, as it is reinforced in this except:

[...] sooner or later everything ends up reduced to a point of view, and you, that are always spoiling human sciences, do not suspect that you spoil a joke. [...] I refuse, then, to think about something I don't believe anymore, [...] I am still scared about my life, but I am not afraid of being alone, it was consciously that I choose the exile [...]. (Nassar, 1987, p. 52)

Despite being diverse, fruition in the literary text runs for dissipation of mental structures organized from an only point of view and this way broadens the repertoire of interpretative possibilities, either through the disorder of preexisting knowledge, or through the order of how this knowledge is confronted in the text, which in Barthes' (2002) conception is: "[...] the one that puts in state of loss, [...] discomfort [...], brings doubts to historical, cultural, psychological bases of the reader, the consistence of his tastes, his values and his memories, brings crisis to his relation towards language" (pp. 23-24), because it is the reader who reads the constructive principles of its organization (Machado, 2003).

Faced with the exposed, it can be stated that the approached themes, when remeaning as aesthetic element, 
guide the reader to meet the literary ambiguity, that through metalinguistic adjust as element that exceeds the reading experience, reaching as well, the inner of humans anxieties, refer necessarily, to the aspects of senses equivalence, built from the human behavior invariances, but that come to be renewed based in raising questionings with the exercise of reading practice.

\section{Conclusion}

The reading of the Nassarian novel is a tour through a language that starts from colloquialisms to the metaphors enriched in a culture systemic plan, translated through a modeling, in which semiotic competence enables an interaction in the meaning process of the chosen model for this study. This fruition process, which contains different languages, gives opportunity to the reader experience a poetics, enriched of intentionality that guides the interpretative practice and this way broadens the possibilities of transformation of the literary work in a universe of implicit meanings to the historic and socio-cultural context, In short, the narrative Um Copo de Cólera in its artistic existence, establishes relations of complementary between static and dynamic models which aim to desautomatize the interpretative look.

\section{References}

Barthes, R. (2002). O prazer do texto (The pleasure of the text). São Paulo: Perspectiva.

Eco, U. (2011). Apocalipticos e integrados (Apocalypse postponed). São Paulo: Perspectiva.

Eco, U. (1993). Interpretação e Superinterpretação (Interpretation and over interpretation). São Paulo: Martins Fontes.

Eco, U. (2013). Obra aberta (The open work). São Paulo: Perspectiva.

Lotman, I. M. (1979). Sobre o problema da tipologia da cultura. In B. Schnaiderman (Ed.), Semiologia (Semiology). São Paulo: Editora Perspectiva.

Lotman, I. M. (1979). Sobre algumas dificuldades de princípio na descrição estrutural de um texto. In B. Schnaiderman (Ed.), Semiologia (Semiology). São Paulo: Editora Perspectiva.

Machado, I. (2003). Escola de Semiótica: A Experiência de Tártu-Moscou para o Estudo da Cultura (Semiotics school: Tartu-Moscow experience to the culture study). São Paulo: Ateliê Editorial.

Nassar, R. (1987). Um copo de cólera (4a ed.) ((A cholera glass (4th ed.)). São Paulo: Brasiliense s.a. 